\title{
Vocational High School Students' Perception in learning English and Its Relation to their Career Aspiration in Yogyakarta
}

\author{
Nana Apriliana', Basikin ${ }^{2}$ \\ Yogyakarta State University, Indonesia ${ }^{1,2}$ \\ Email: Nanaapriliana124@yahoo.com¹
}

Submitted: 15/05/2020

Revised: 19/06/2020

Accepted: 03/11/2020

E-ISSN : $2579-4574$

P-ISSN : 2549-7359

\begin{abstract}
In Indonesia, Vocational High Schools (VHSs) are designed to prepare graduates for a specific job. Selecting the types of English that suits the needs of vocational students is paramount importance to support their vocational skill in the ASEAN Economic Community (AEC). This study aims to reveal: (1) Vocational High School (VHS) students' English perceived needs, (2) VHS students' career aspirations toward study program they are taking, (3) the effect of students' perception of their English program (EGP and ESP) on their career aspirations, and (4) the differences in the students' perception of their English program (EGP and ESP) by demographic variables (gender and study program). This was quantitative research in the form of a correlational study. The data were analyzed using descriptive analysis, multiple regression, and multivariate analysis of variance (MANOVA). The findings indicated that: (1) Most VHS students' English perceived need was ESP. Nevertheless, it was also undeniable that they also still needed EGP for their English before they took ESP. (2) Most VHS students did not have mature career aspirations related to the study program they were taking at vocational high school. (3) Furthermore, there was a significant effect of students' perception (EGP and ESP) on their career aspirations. (4) Regarding differences between male and female's perception of English program and differences in students' study program, the results of this study revealed significant differences among them.
\end{abstract}

Keywords: Career Aspiration, EGP, ESP, Perception

https://ojs.unm.ac.id/eralingua

This work is licensed under a Creative Commons Attribution-NonCommercial 4.0 International License 


\section{INTRODUCTION}

Vocational high schools (VHSs) have become a very important concern in the development of the workforce in Indonesia nowadays. This is particularly because the Central Bureau of Indonesian Statistics or Badan Pusat Statistik (BPS) predicts that Indonesia will enjoy a demographic bonus era in 2020-2035. During this period, the productive population is projected to reach $64 \%$ of the total number of Indonesian population (297 million people). Then, in 2035, it is projected at 305.6 million people (BPS: Proyeksi Penduduk Indonesia 2010-2035, 2013).

According to the House Committee on Education and Labor (HCEL), vocational education is a form of talent development, basic education skills, and habits that focus on the world-work (Fakhri \& Yufridawati, 2009). Evans and Edwin (1978) stated that vocational education is part of the education system that prepares individuals for a job or group of workers. The purpose of vocational education can then be viewed on a spectrum with training for specific, narrowly defined jobs at one end and, at the other, a more general preparation designed to help young people leads productive and fulfilling adult lives as workers and citizens. Vocational education is expected to be able to open up broader thinking for graduates so that they can develop their potential skill. VHS is one of the education institutions responsible for producing skilled workers. Therefore, it can be concluded that one of the characteristics of vocational education that distinguishes it from other types of education is its orientation in preparing students to enter the workforce.

In Indonesia, the design of VHSs is contained in the Act of the Republic of Indonesia Number 20 the Year 2003 Chapter VI Article 15 of the National Education System. It is explained that vocational education is a secondary education program to prepare learners for a specific job. In other words, vocational education has to equip students with the knowledge and skills related to productivity and all subjects are expected to be designed for employment areas. In preparing learners for a specific job, selecting the types of English language teaching that suits the needs of vocational students is paramount importance. The selection of the types of English language teaching learned at school will greatly assist VHSs' graduates in workforce competitions. The types of English language teaching can be differentiated into two major types, namely General English or English for General Purposes (EGP) and English for Specific Purposes (ESP) (Hutchinson \& Waters, 1987). The difference between EGP and ESP is based on 2 perceived needs whether teaching for the selective specification of goals or teaching for general (not specifiable). Rahmat and Al As'ary (2017) EGP focuses on the applications in general situations: performing in English on personal or social levels or using English in casual conversations and functions. Meanwhile, ESP is based on the learners' needs by analyzing the linguistic characteristics of learners' specialist area of work or study (Hutchinson \& Waters, 1987: 8). Trimble (1985) English for general purposes is, in fact, the foundation for later attainments in the specialist field. Therefore, Studying EGP is important for students before they take ESP.

Perception is a process where a person will form an impression of someone or something (Ahen, 2009). The process of a person perceiving something is built by 
individual observation. Someone's observation in perceiving something will generate his assumption. It will bring his subjective feelings, opinions, and emotions finding of its meaning based on what he perceives. Understanding the students' perception of English they want is very important to their future careers. Feng (2013) stated that some scholars advocate that the role of student perceptions is of great importance in language teaching practice. By accommodating students' perception of English they want, it will motivate them to learn English seriously and has a good impact on their future career.

Career aspiration defined as long-term individual work-related goals that represent an individual's orientation containing ambitions, hopes, dreams, and a desired career goal under ideal conditions to be achieved (Pfingst, 2015; Linderman, 2010; Lerdpornkulrat, Koul, \& Sujivorakul, 1999). The long-term individual workrelated goals can be planned during adolescence. Most of the VHS students are adolescents. It is the most appropriate time for them to decide their career aspiration (Lerdpornkulrat et al., 1999). By determining career aspirations, they can start planning and exploring the supporting factors to achieve their real future career. Besides their vocational skill, English is one of the supporting factors in achieving their career aspiration in the AEC era. Warden and Lin (cited in Hua \& Beverton, 2013) in their study have shown that students have strong instrumental motivation in their English studies, associated with career improvement. In this study, students' career aspiration is very close to the students' study program. Therefore, the writer assumes that students' career aspiration refers to study program they are taking.

However, there is still a problem related to the implementation of English language teaching in VHSs in Indonesia. The government implements EGP in Academic High School (AHS) and Vocational High School (VHS). They generalize the needs of English between VHS students and AHS students that only focus on language proficiency. It is contrary to VHS demand that is preparing students to work. Based on preliminary research of VHS English teachers, it is showed that the government and English teachers have an opposite view on the VHS students' needs of English. The government implements EGP. Meanwhile, English teachers believe that VHS students need English that is relevant to their vocational skills like ESP. Their belief is supported by many studies of English language teaching said that English would be more meaningful to the majority of VHS students if they could see its relevance to their specific major and their potential future career (Hua \& Beverton, 2013; Kusni, Syamwil, \& Refnaldi, 2014; Arslan \& Akbarov, 2012).

Therefore, the present study aims at investigating the students' perception of the types of English programs in relation to their career aspirations answering the research question (1) what are VHS students' English perceived need?, (2) What are VHS students' career aspiration toward study program they are taking?. This present study also proves the research hypotheses (1) there is a significant effect of students' perception of their English program (EGP and ESP) on their career aspirations, (2) there is a significant difference in students' perception of their English program due to differences in gender and study program. It is expected to get enlightenment on two different views on the types of English that are suitable 
for VHS students between English teachers and government. Besides, this study is also expected to help English teachers to choose the types of English program that VHS students want to smooth the learning process and improve students' interest in English and their learning motivation.

\section{RESEARCH METHOD}

This study was quantitative research in the form of a correlational study. This study was intended to investigate Vocational High School (VHS) students' perception of the types of English programs (ESP and EGP) and their career aspirations, to find out the effect of students' perception of their English program (EGP and ESP) on their career aspirations. It also examined how VHS students' perception of the types of English programs (ESP and EGP) differed by gender.

This study was conducted in five districts in Yogyakarta Special Territory (i.e. Sleman, Bantul, Kulon Progo, Gunung Kidul, and Yogyakarta city). The subjects were 291 male and 235 female students grade X students of ten public VHS's in Yogyakarta in their second-semester. Besides, this study also took four study programs as the sample of vocational study program based on the level of frequency of graduates using English in the workplace. Hospitality and culinary arts study programs as the most required English in the workplace. Meanwhile, computer engineering and automotive study programs as the lower English requirement (Hua \& Beverton, 2013). The following table was the detail descriptive statistics of respondents.

Table 1. Descriptive Statistics of Respondents' Demographic Variables

\begin{tabular}{cclc}
\hline \multicolumn{2}{c}{ Gender } & \multicolumn{2}{c}{ Study Program } \\
\hline & $\mathbf{N}(\%)$ & \multicolumn{1}{c}{$\mathbf{N}(\%)$} \\
\hline Male & 291 & Hospitality & $144(27.4 \%)$ \\
\cline { 3 - 4 } & $(55.3 \%)$ & Culinary Arts & $100(19 \%)$ \\
\hline Female & 235 & Computer Engineering & $148(28.1 \%)$ \\
\cline { 3 - 4 } & $(44.7 \%)$ & Automotive & $134(25.5 \%)$ \\
\hline Total & $\mathbf{5 2 6 ( 1 0 0 \% )}$ & & $\mathbf{5 2 6 ( 1 0 0 \% )}$ \\
\hline
\end{tabular}

The research instruments used in this study were in the form of questionnaires. There were two types of questionnaires used in this research namely perception questionnaire and career aspiration questionnaire. A perception questionnaire was used to deploy the participants' perception of the English program they perceived need (ESP and EGP). It contained four specific related items (i.e. experience, expectation, goal/target, need), and the four specific-related items consisted of English for General Purposes (EGP) and English for Specific Purposes (ESP) questions. It was adapted from Tabatabaei \& Mokhtari (2014). Their questionnaire was in the form of a Likert-scale ranging from a very strong need to very little need. Their content validity was established by asking four experts to give their opinions on the first draft of the questionnaire. They were experts in research methodology, text and discourse analysis, testing, and phonology. Meanwhile, the 
reliability was 0.85 . Therefore, in this study, some modifications were made to fit the participants. The modifications were by the wording, some of them changing the content that was less relevant to vocational high school students in the Indonesian context, changing the layout of the items, translating the items from English to Indonesian, and changing the Likert-scale ranging from 1 (strongly disagree) to 4 (strongly agree) to ease the students in choosing their choice. The following were the EGP question items, the ESP question items, and the ideal score of perception questionnaire tables sequentially.

Table 2. EGP Question Items

\begin{tabular}{lc}
\hline \multicolumn{1}{c}{ Aspect } & Item Number \\
\hline $\begin{array}{l}\text { I have learned English text about history, heroes, folklore, and world } \\
\text { tourist attractions. }\end{array}$ & $\mathrm{P}(1)$ \\
\hline $\begin{array}{l}\text { English I learned in school will help me get a job that interests me out of } \\
\text { my study program after graduating from vocational high school. }\end{array}$ & $\mathrm{P}(4)$ \\
\hline $\begin{array}{l}\text { English about an introduction, congratulation, and giving information } \\
\text { will help me working in the field that I am interested in out of my study } \\
\text { program. }\end{array}$ & $\mathrm{P}(7)$ \\
\hline $\begin{array}{l}\text { My main priority in learning English is to communicate with foreign } \\
\text { people. }\end{array}$ & $\mathrm{P}(9)$ \\
\hline I study English in school aims to pass a national exam. & $\mathrm{P}(10)$ \\
\hline I need to read English textbooks, magazines, and newspapers to enrich \\
my English vocabulary.
\end{tabular}

Table 3. ESP Question Items

\begin{tabular}{lc}
\hline \multicolumn{1}{c}{ Aspect } & Item Number \\
\hline $\begin{array}{l}\text { I have learned English in a specific field related to my study program. } \\
\text { I have learned to read English text in a specific field related to my study } \\
\text { program. }\end{array}$ & $\mathrm{P}(2)$ \\
\hline $\begin{array}{l}\text { Learning specific English related to the study program is my main goal to } \\
\text { help me working in a specific field. }\end{array}$ & $\mathrm{P}(5)$ \\
\hline $\begin{array}{l}\text { English I learned in school will help me get a job in a specific field related } \\
\text { to my study program. }\end{array}$ & $\mathrm{P}(6)$ \\
\hline $\begin{array}{l}\text { Learning specific English focusing on my study program will help me to } \\
\text { work in the field related to my study program. }\end{array}$ & $\mathrm{P}(8)$ \\
\hline $\begin{array}{l}\text { I hope to learn English in a specific field related to my study program. } \\
\text { I need to write English text related to my study program. }\end{array}$ & $\mathrm{P}(11)$ \\
\hline
\end{tabular}


Table 4. The Ideal Score of Perception Questionnaire

\begin{tabular}{ccccc}
\hline \multicolumn{4}{c}{ Perception Questionnaire } & \\
\hline Likert Scale & Score & Formula & $\begin{array}{c}\text { Total Score } \\
(\%)\end{array}$ & Interpretation \\
\hline Strongly Disagree & 1 & $1 \times 526=526$ & $\begin{array}{c}1-526 \\
(0 \%-25 \%)\end{array}$ & Strongly Disagree \\
\hline Disagree & 2 & $2 \times 526=1052$ & $\begin{array}{c}527-1052 \\
(25.1 \%-50 \%)\end{array}$ & Disagree \\
\hline Agree & 3 & $3 \times 526=1578$ & $\begin{array}{c}1053-1578 \\
(50.1 \%-75 \%)\end{array}$ & Agree \\
\hline Strongly Agree & 4 & $4 \times 526=2104$ & $\begin{array}{c}1579-2104 \\
(75.1 \%-100 \%)\end{array}$ & Strongly Agree \\
\hline
\end{tabular}

Meanwhile, a career aspiration questionnaire was used to measure students' career aspirations. This questionnaire contained four specific related items. The four specific-related items consisted of related career aspiration to study program questions and non-related career aspiration to study program questions. The items (i.e. leadership aspiration, achievement aspiration, educational aspiration) adapted from Gregor and O' Brien (2016) A study of Career Aspiration Scale-Revised (CAS-R). The 24-item CAS-R model exhibited good model fit with undergraduate women: Satorra-Bentler SB $\chi_{2}(241, \mathrm{~N}=328)=909.45, \mathrm{p}<.05, \mathrm{RMSEA}=.09(.086 ; .098), \mathrm{CFI}=$ .95 , TLI $=.94$ (Gregor \& O'Brien, 2016). The modification of questionnaire was by translating the items from English to Indonesian, Eliminating the items that were less relevant to vocational high school students in Indonesia context, and changing the rated scale from 5-point Likert scale to 4-point Likert scale ranging from 1 (very untrue of me) to 4 (very true of me) to ease the students in choosing their choice. One item (i.e. employment aspiration) was added to find out students' desire for their future employment. The following were related career aspiration items to study program, non-related career aspiration items to study program, and the ideal score of career aspiration questionnaire tables sequentially.

Table 5. Related Career Aspiration Items to Study Program

\begin{tabular}{lc}
\hline \multicolumn{1}{c}{ Aspect } & Item Number \\
\hline I want to be the best worker in a specific field related to my study & CA (1) \\
program. & \\
\hline I want to have responsibility for the future direction of the business that & CA (2) \\
I am establishing related to my study program. & \\
\hline $\begin{array}{l}\text { After graduating from vocational high school, I plan to work in a specific } \\
\text { field related to my study program before going to university. }\end{array}$ & CA (3) \\
\hline I hope to work in a specific field related to my study program for the & CA (4) \\
whole of my life. & \\
\hline I think about working in a specific field related to my study program for a & CA (5) \\
while before getting a job I am interested in. & \\
I plan to participate in specific training related to my study program to & CA (6)
\end{tabular}


improve my knowledge.

Being one of the outstanding at work in a specific field related to my study program is very important to me.

I plan to raise the top position of leadership in the specific field related to my study program.

Table 6. Non-Related Career Aspiration items to Study Program

\begin{tabular}{lc}
\hline \multicolumn{1}{c}{ Aspect } & Item Number \\
\hline $\begin{array}{l}\text { Attaining leadership status in my business out of my study program is } \\
\text { very important to me. }\end{array}$ & CA (7) \\
\hline I know that everyone will recognize my achievements out of my study & CA (9) \\
program. & CA (10) \\
\hline I strongly encourage my education to support my career out of my study \\
program in the future.
\end{tabular}

Table 7. The Ideal Score of Career Aspiration Questionnaire

\begin{tabular}{ccccc}
\hline \multicolumn{1}{c}{ Career Aspiration Questionnaire } & \\
\hline Very untrue of me & 1 & $1 \times 526=526$ & $\begin{array}{c}1-526 \\
(\%)\end{array}$ & Very untrue of me \\
\hline Untrue of me & 2 & $2 \times 526=1052$ & $\begin{array}{c}527-1052 \\
(25.1 \%-50 \%)\end{array}$ & Untrue of me \\
\hline True of me & 3 & $3 \times 526=1578$ & $\begin{array}{c}1053-1578 \\
(50.1 \%-75 \%)\end{array}$ & True of me \\
\hline Very True of me & 4 & $4 \times 526=2104$ & $\begin{array}{c}1579-2104 \\
(75.1 \%-100 \%)\end{array}$ & Very True of me \\
\hline
\end{tabular}

Content validity and construct validity were used to measure the perception and career aspiration instruments. The instrument was validated by the expert of English from the Graduate Program at Yogyakarta State University. Nurgiyantoro et al. (2015: 415), the testing of content and construct validity should be performed by a person who is competent in the field. The expert checked the relevance of the questions to the questionnaires' purpose, possible wording, type, and order of questions. Then, the researcher used Pearson Product-moment to check the validity of the instruments. Meanwhile, in testing the reliability of the instruments, the pilot study was conducted to 155 vocational high school students out of the sample. It 
was calculated using Cronbach's Alpha in SPSS version 24. The reliability test of the perception instrument showed Crombach's Alpha 0.753 and career aspiration instrument showed Crombach's Alpha 0.719 were considered as reliable. Hajjar (2014) Cronbach's Alpha computed and the results were compared with the 0.7 level recommended as a cut-off point, which showed that scales were reliable.

In analyzing the data, descriptive analysis used to know the questionnaires frequency of each Likert scale item, mean, deviation standard of variable. Multiple regression used to examine the effect of students' perception of their English program (EGP and ESP) on their career aspirations. Meanwhile, multivariate analysis of variance (MANOVA) was to measure whether students' perception of English program (EGP and ESP) was differed by (1) gender (i.e. male and female) and (2) study programs (i.e. Hospitality, Culinary Arts, Computer Engineering, and Automotive) using SPSS version 24.

\section{RESULT AND DISCUSSION}

\section{VHS Students' Need Analysis in Studing English}

This sub-section focused on the VHS students' perception of their English program. The descriptive statistic was used to analyze students' perceptions of their English program (EGP and ESP). The four factors that mentioned previously were divided into 2 parts (i.e. EGP and ESP question items). The following tables were the EGP and ESP question items that would be analyzed.

\section{Perception Questionnaire of EGP Question Items}

The following table was the result of EGP question items. There were seven items would be analyzed.

Table 8. Summary of EGP Question Scores and Interpretations

\begin{tabular}{|c|c|c|c|c|c|}
\hline Item Number & Likert Scale & $f$ & Score & Total Score (\%) & Interpretation \\
\hline \multirow[t]{4}{*}{$\mathrm{P}(1)$} & Strongly Disagree & 26 & 26 & \multirow{4}{*}{$\begin{array}{c}1559 \\
(74.09 \%)\end{array}$} & \multirow[t]{4}{*}{ Agree } \\
\hline & Disagree & 88 & 176 & & \\
\hline & Agree & 291 & 873 & & \\
\hline & Strongly Agree & 121 & 484 & & \\
\hline \multirow[t]{4}{*}{$P(4)$} & Strongly Disagree & 5 & 325 & \multirow{4}{*}{$\begin{array}{c}1769 \\
(84.08 \%)\end{array}$} & \multirow{4}{*}{$\begin{array}{c}\text { Strongly } \\
\text { Agree }\end{array}$} \\
\hline & Disagree & 38 & 76 & & \\
\hline & Agree & 244 & 732 & & \\
\hline & Strongly Agree & 239 & 956 & & \\
\hline \multirow[t]{4}{*}{$\mathrm{P}(7)$} & Strongly Disagree & 4 & 4 & \multirow{4}{*}{$\begin{array}{c}1782 \\
(84.70 \%)\end{array}$} & \multirow{4}{*}{$\begin{array}{c}\text { Strongly } \\
\text { Agree }\end{array}$} \\
\hline & Disagree & 30 & 120 & & \\
\hline & Agree & 250 & 810 & & \\
\hline & Strongly Agree & 242 & 748 & & \\
\hline \multirow[t]{4}{*}{$\mathrm{P}(9)$} & Strongly Disagree & 23 & 23 & \multirow{4}{*}{$\begin{array}{c}1553 \\
(73.81 \%)\end{array}$} & \multirow[t]{4}{*}{ Agree } \\
\hline & Disagree & 117 & 234 & & \\
\hline & Agree & 248 & 744 & & \\
\hline & Strongly Agree & 138 & 552 & & \\
\hline$P(10)$ & Strongly Disagree & 41 & 41 & 1527 & Agree \\
\hline
\end{tabular}




\begin{tabular}{|c|c|c|c|c|c|}
\hline & Disagree & 115 & 230 & \multirow[t]{3}{*}{$(72.58 \%)$} & \\
\hline & Agree & 224 & 672 & & \\
\hline & Strongly Agree & 146 & 584 & & \\
\hline \multirow[t]{4}{*}{$P(13)$} & Strongly Disagree & 5 & 5 & \multirow{4}{*}{$\begin{array}{c}1652 \\
(78.52 \%)\end{array}$} & \multirow{4}{*}{$\begin{array}{c}\text { Strongly } \\
\text { Agree }\end{array}$} \\
\hline & Disagree & 82 & 164 & & \\
\hline & Agree & 273 & 819 & & \\
\hline & Strongly Agree & 166 & 664 & & \\
\hline \multirow[t]{4}{*}{$P(14)$} & Strongly Disagree & 18 & 18 & \multirow{4}{*}{$\begin{array}{c}1576 \\
(74.90 \%)\end{array}$} & \multirow[t]{4}{*}{ Agree } \\
\hline & Disagree & 116 & 232 & & \\
\hline & Agree & 242 & 726 & & \\
\hline & Strongly Agree & 150 & 600 & & \\
\hline
\end{tabular}

In terms of EGP questions, the interpretation showed that 3 of 7 EGP questions (42.86\%) got "strongly agree" responses and 4 of 7 EGP questions (57.14\%) got "agree" responses. It meant that $42.86 \%$ of VHS students strongly agree to receive EGP for their English perceived need. Based on EGP results, it could be highlighted in terms of VHS students' expectation factor that they strongly expect to learn English such as introduction, congratulation, and giving information in school to help them get a job that interests them out of their study program after graduating from vocational high school. Then, in terms of VHS students' perceived need factor, they also strongly need to read English textbooks, magazines, and newspapers to enrich their English vocabulary.

The $57.14 \%$ of remaining VHS students in terms of VHS students' past experience factor, they agreed that they have learned English text about history, heroes, folklore, and world tourist attractions. In terms of VHS students' goal factor, they agreed that their goals in learning English are to communicate with foreign people and to pass a national exam. Then, in terms of VHS students' perceived need factor, they also needed to listen to English songs, to watch English movies and TV programs to support their future career.

\section{Perception Questionnaire of ESP Question Items}

The following tables were the result of ESP question items. There were seven items would be analyzed.

Table 9. Summary of ESP Question Scores and Interpretations

\begin{tabular}{|c|c|c|c|c|c|}
\hline Item Number & Likert Scale & $f$ & Score & Total Score (\%) & Interpretation \\
\hline \multirow[t]{4}{*}{$P(2)$} & Strongly Disagree & 51 & 51 & \multirow{4}{*}{$\begin{array}{c}1385 \\
(65.83 \%)\end{array}$} & \multirow[t]{4}{*}{ Agree } \\
\hline & Disagree & 180 & 360 & & \\
\hline & Agree & 206 & 618 & & \\
\hline & Strongly Agree & 89 & 356 & & \\
\hline \multirow[t]{4}{*}{$P(3)$} & Strongly Disagree & 48 & 48 & \multirow{4}{*}{$\begin{array}{c}1361 \\
(84.69 \%)\end{array}$} & \multirow{4}{*}{$\begin{array}{l}\text { Strongly } \\
\text { Agree }\end{array}$} \\
\hline & Disagree & 190 & 380 & & \\
\hline & Agree & 219 & 657 & & \\
\hline & Strongly Agree & 69 & 276 & & \\
\hline \multirow[t]{3}{*}{$P(5)$} & Strongly Disagree & 16 & 16 & \multirow{3}{*}{$\begin{array}{c}1566 \\
(74.43 \%)\end{array}$} & \multirow[t]{3}{*}{ Agree } \\
\hline & Disagree & 119 & 238 & & \\
\hline & Agree & 252 & 756 & & \\
\hline
\end{tabular}




\begin{tabular}{|c|c|c|c|c|c|}
\hline & Strongly Agree & 139 & 556 & & \\
\hline \multirow[t]{4}{*}{$P(6)$} & Strongly Disagree & 8 & 8 & \multirow{4}{*}{$\begin{array}{c}1676 \\
(79.66 \%)\end{array}$} & \multirow{4}{*}{$\begin{array}{c}\text { Strongly } \\
\text { Agree }\end{array}$} \\
\hline & Disagree & 57 & 144 & & \\
\hline & Agree & 290 & 870 & & \\
\hline & Strongly Agree & 171 & 684 & & \\
\hline \multirow[t]{4}{*}{$P(8)$} & Strongly Disagree & 9 & 9 & \multirow{4}{*}{$\begin{array}{c}1687 \\
(80.18 \%)\end{array}$} & \multirow{4}{*}{$\begin{array}{c}\text { Strongly } \\
\text { Agree }\end{array}$} \\
\hline & Disagree & 60 & 120 & & \\
\hline & Agree & 67 & 810 & & \\
\hline & Strongly Agree & 102 & 748 & & \\
\hline \multirow[t]{4}{*}{$P(11)$} & Strongly Disagree & 9 & 9 & \multirow{4}{*}{$\begin{array}{c}1673 \\
(79.52 \%)\end{array}$} & \multirow{4}{*}{$\begin{array}{c}\text { Strongly } \\
\text { Agree }\end{array}$} \\
\hline & Disagree & 67 & 134 & & \\
\hline & Agree & 270 & 810 & & \\
\hline & Strongly Agree & 180 & 720 & & \\
\hline \multirow[t]{4}{*}{$P(12)$} & Strongly Disagree & 14 & 14 & \multirow{4}{*}{$\begin{array}{c}1607 \\
(76.38 \%)\end{array}$} & \multirow{4}{*}{$\begin{array}{c}\text { Strongly } \\
\text { Agree }\end{array}$} \\
\hline & Disagree & 102 & 204 & & \\
\hline & Agree & 251 & 753 & & \\
\hline & Strongly Agree & 159 & 636 & & \\
\hline
\end{tabular}

In terms of ESP questions, the interpretation showed that 5 of 7 ESP questions (71.43\%) got "strongly agree" responses and 2 of 7 ESP questions (28.57\%) got "agree" responses. It meant that $71.43 \%$ of VHS students strongly agree to receive ESP for their English perceived need. Based on ESP results, it could be highlighted in terms of VHS students' expectation factor that they strongly expect to learn specific English focusing on their study program to help them get a job in the field related to their study program. In terms of VHS students' past experience factor, they have read English text in a specific field related to their study program. In terms of VHS students' perceived need factor, they also strongly need to write English text related to their study program.

The $28.57 \%$ of remaining VHS students in terms of VHS students' past experience factor, they agreed that they have learned English in a specific field related to their study program. I term of VHS students' goal factor, they also agreed that their goal in learning English is to learn specific English related to the study program to help them working in a specific field.

Based on the both findings of EGP and ESP question items, the results showed that students' perceived need in both types of English. The students tended to choose both of them. It can be seen from the interpretation of students' responses to each item of EGP and ESP question items that chose "Strongly agree" and "agree" responses. Even though VHS students had the same responses, there were different percentages of their "strongly agree" and "agree" responses. In terms of "strongly agree" response, EGP got $42.86 \%$ and ESP got $71.43 \%$. Afterward, in the "agree" response, EGP got $57.14 \%$ and ESP got $28.57 \%$. It indicated that they strongly agreed to have ESP for their English (71.43\%). Nevertheless, it was also undeniable that they agreed that they also still needed EGP (57.14\%) for their English because studying EGP was important for students before they take English for special purposes. 
This finding was in line with the previous study stated that English for general purposes that provides basic knowledge and skills of the English language, in fact, the foundation for later attainments in the specialist field (Trimble, 1985: 6; Rahmat \& Al As'ary, 2017). These findings also clearly explained by previous theories (Hua \& Beverton, 2013; Kusni et al., 2014; Arslan \& Akbarov, 2012) English would be more meaningful to the majority of VHS students if they could see its relevance to their specific major and their potential future career.

\section{VHS Students' Career Aspirations}

This sub-section focused the VHS students' career aspirations. The descriptive analysis was also used to investigate VHS students' career aspirations The four factors that mentioned previously were divided into 2 parts (i.e. Related career aspiration items to study program, and Non-related career aspiration items to the study program). The following tables were related career aspiration items to study program, and non-related career aspiration items to the study program that would be analyzed.

\section{Related Career Aspiration Items to Study Program}

The following table was the result of career aspiration question items related to the study program. Eight items would be analyzed.

Table 10. Summary of Related Career Aspiration Items to Study Program and Interpretations

\begin{tabular}{|c|c|c|c|c|c|}
\hline Item Number & Likert Scale & $f$ & Score & Total Score (\%) & Interpretation \\
\hline \multirow[t]{4}{*}{$C A(1)$} & Very untrue of me & 6 & 6 & \multirow{4}{*}{$\begin{array}{c}1777 \\
(84.46 \%)\end{array}$} & \multirow{4}{*}{$\begin{array}{l}\text { Very True of } \\
\text { me }\end{array}$} \\
\hline & Untrue of me & 35 & 70 & & \\
\hline & True of me & 239 & 717 & & \\
\hline & Very true of me & 246 & 984 & & \\
\hline \multirow[t]{4}{*}{$C A(2)$} & Very untrue of me & 0 & 0 & \multirow{4}{*}{$\begin{array}{c}1879 \\
(89.31 \%)\end{array}$} & \multirow{4}{*}{$\begin{array}{l}\text { Very True of } \\
\text { me }\end{array}$} \\
\hline & Untrue of me & 12 & 24 & & \\
\hline & True of me & 201 & 603 & & \\
\hline & Very true of me & 313 & 1252 & & \\
\hline \multirow[t]{4}{*}{ CA (3) } & Very untrue of me & 19 & 19 & \multirow{4}{*}{$\begin{array}{c}1456 \\
(69.20 \%)\end{array}$} & \multirow[t]{4}{*}{ True of me } \\
\hline & Untrue of me & 162 & 324 & & \\
\hline & True of me & 267 & 801 & & \\
\hline & Very true of me & 78 & 312 & & \\
\hline \multirow[t]{4}{*}{ CA (4) } & Very untrue of me & 32 & 32 & \multirow{4}{*}{$\begin{array}{c}1310 \\
(62.26 \%)\end{array}$} & \multirow[t]{4}{*}{ True of me } \\
\hline & Untrue of me & 254 & 508 & & \\
\hline & True of me & 190 & 570 & & \\
\hline & Very true of me & 50 & 200 & & \\
\hline \multirow[t]{4}{*}{$\mathrm{CA}(5)$} & Very untrue of me & 28 & 28 & \multirow{4}{*}{$\begin{array}{c}1409 \\
(66.97 \%)\end{array}$} & \multirow[t]{4}{*}{ True of me } \\
\hline & Untrue of me & 179 & 358 & & \\
\hline & True of me & 253 & 759 & & \\
\hline & Very true of me & 66 & 264 & & \\
\hline \multirow[t]{3}{*}{ CA (6) } & Very untrue of me & 3 & 3 & \multirow{3}{*}{$\begin{array}{c}1655 \\
(78.66 \%)\end{array}$} & \multirow{3}{*}{$\begin{array}{l}\text { Very True of } \\
\text { me }\end{array}$} \\
\hline & Untrue of me & 82 & 164 & & \\
\hline & True of me & 276 & 828 & & \\
\hline
\end{tabular}




\begin{tabular}{|c|c|c|c|c|c|}
\hline & Very true of me & 165 & 660 & & \\
\hline \multirow[t]{4}{*}{ CA (8) } & Very untrue of me & 21 & 21 & \multirow{4}{*}{$\begin{array}{c}1573 \\
(74.76 \%)\end{array}$} & \multirow[t]{4}{*}{ True of me } \\
\hline & Untrue of me & 122 & 244 & & \\
\hline & True of me & 224 & 672 & & \\
\hline & Very true of me & 159 & 636 & & \\
\hline \multirow[t]{4}{*}{ CA (13) } & Very untrue of me & 18 & 18 & \multirow{4}{*}{$\begin{array}{l}1641 \\
(78 \%)\end{array}$} & \multirow{4}{*}{$\begin{array}{c}\text { Very True of } \\
\text { me }\end{array}$} \\
\hline & Untrue of me & 82 & 164 & & \\
\hline & True of me & 245 & 735 & & \\
\hline & Very true of me & 181 & 724 & & \\
\hline
\end{tabular}

In terms of related career aspiration items to study program, the interpretation showed that 4 of 8 questions (50\%) got "very true of me" responses, and 4 of 8 questions (50\%) got "true of me" responses. It meant that $50 \%$ of VHS students are very true that their career aspiration is related to their study program. Based on related career aspiration items to study program results, it could be highlighted in terms of achievement aspiration factor that VHS students are very true to be the best worker in the specific field related to their study program. In terms of leadership aspiration factor, VHS students are very true to have responsibility for the future direction of the business that they are establishing and to plan raising the top position of leadership in the specific field related to their study program. Then, in terms of educational aspiration factor, VHS students are very true planning to participate in specific training related totheir study program to improve their knowledge.

The $50 \%$ of remaining VHS students of educational aspiration factor, VHS students are true planning to work in a specific field related to their study program before going to university. In terms of employment aspiration factor, VHS students are true to work in a specific field related to their study program for the whole of their life and they are also true to work in a specific field related to their study program for a while before getting a job they are interested in. Furthermore, in terms of achievement aspiration factor, VHS students are true to be one of the outstanding at work in a specific field related to their study program is very important to them.

\section{Non-Related Career Aspiration Items to Study Program}

The following table was the result of non-related career aspiration items to study program. Seven items would be analyzed.

Table 11. Summary of Non-Related Career Aspiration Items to Study Program and Interpretations

\begin{tabular}{|c|c|c|c|c|c|}
\hline Item Number & Likert Scale & $f$ & Score & Total Score (\%) & Interpretation \\
\hline \multirow[t]{4}{*}{$\mathrm{CA}(7)$} & Very untrue of me & 2 & 2 & \multirow{4}{*}{$\begin{array}{c}1801 \\
(85.6 \%)\end{array}$} & \multirow{4}{*}{$\begin{array}{c}\text { Very True of } \\
\text { me }\end{array}$} \\
\hline & Untrue of me & 43 & 86 & & \\
\hline & True of me & 211 & 633 & & \\
\hline & Very true of me & 270 & 1080 & & \\
\hline \multirow[t]{3}{*}{ CA (9) } & Very untrue of me & 19 & 19 & \multirow{3}{*}{$\begin{array}{c}1544 \\
(73.38 \%)\end{array}$} & \multirow[t]{3}{*}{ True of me } \\
\hline & Untrue of me & 87 & 174 & & \\
\hline & True of me & 329 & 987 & & \\
\hline
\end{tabular}




\begin{tabular}{|c|c|c|c|c|c|}
\hline & Very true of me & 91 & 364 & & \\
\hline \multirow[t]{4}{*}{$C A(10)$} & Very untrue of me & 10 & 10 & \multirow{4}{*}{$\begin{array}{c}1733 \\
(82.37 \%)\end{array}$} & \multirow{4}{*}{$\begin{array}{c}\text { Very True of } \\
\text { me }\end{array}$} \\
\hline & Untrue of me & 56 & 112 & & \\
\hline & True of me & 229 & 687 & & \\
\hline & Very true of me & 231 & 924 & & \\
\hline \multirow[t]{4}{*}{ CA (11) } & Very untrue of me & 9 & 9 & \multirow{4}{*}{$\begin{array}{c}1706 \\
(81.08 \%)\end{array}$} & \multirow{4}{*}{$\begin{array}{c}\text { Very True of } \\
\text { me }\end{array}$} \\
\hline & Untrue of me & 87 & 174 & & \\
\hline & True of me & 197 & 591 & & \\
\hline & Very true of me & 233 & 932 & & \\
\hline \multirow[t]{4}{*}{$\mathrm{CA}(12)$} & Very untrue of me & 8 & 8 & \multirow{4}{*}{$\begin{array}{c}1796 \\
(85.36 \%)\end{array}$} & \multirow{4}{*}{$\begin{array}{c}\text { Very True of } \\
\text { me }\end{array}$} \\
\hline & Untrue of me & 28 & 56 & & \\
\hline & True of me & 228 & 684 & & \\
\hline & Very true of me & 262 & 1048 & & \\
\hline \multirow[t]{4}{*}{ CA (14) } & Very untrue of me & 8 & 8 & \multirow{4}{*}{$\begin{array}{c}1769 \\
(84.08 \%)\end{array}$} & \multirow{4}{*}{$\begin{array}{c}\text { Very True of } \\
\text { me }\end{array}$} \\
\hline & Untrue of me & 52 & 104 & & \\
\hline & True of me & 207 & 621 & & \\
\hline & Very true of me & 259 & 1036 & & \\
\hline \multirow[t]{4}{*}{ CA (15) } & Very untrue of me & 34 & 34 & \multirow{4}{*}{$\begin{array}{c}1655 \\
(78.66 \%)\end{array}$} & \multirow{4}{*}{$\begin{array}{c}\text { Very True of } \\
\text { me }\end{array}$} \\
\hline & Untrue of me & 72 & 144 & & \\
\hline & True of me & 203 & 609 & & \\
\hline & Very true of me & 217 & 868 & & \\
\hline
\end{tabular}

In terms of non-related career aspiration items to study program, the interpretation showed that 6 of 7 questions (85.71\%) got "very true of me" responses, and 1 of 7 questions (14.29\%) got "true of me" responses. It meant that $85.71 \%$ of VHS students are very true that their career aspiration is not related to their study program. Based on non-related career aspiration items to study program results, in terms of leadership aspiration factor, VHS students are very true to attain leadership status in their business out of their study program is very important to them. In terms of educational aspiration factor, VHS students are very true to strongly encourage their education to support the career out of their study program in the future. In terms of achievement aspiration factor, VHS students are very true to be the greatest businessman and plan to advance their own business out of their study program. In terms of employment aspiration factor, VHS students are very true to establish their own business in the field that they are interested in out of their study program. Surprisingly, it is also very true that VHS students have not thought about what they would do after graduating from vocational high school.

The $14.29 \%$ of remaining VHS students are true that their career aspiration is not related to their study program. In terms of achievement aspiration factor, VHS students are true that everyone will recognize their achievements out of their study program. Based on the both findings of career aspiration questions between related career aspiration items to study program and non-related career aspiration items to study program, it showed that in terms of "very true of me" response, related career aspiration items to study program got $50 \%$ and non-related career aspiration items to study program got $85.71 \%$. Afterward, in "true of me" response, related career aspiration items to study program got $50 \%$ and non-related career aspiration 
items to study program got $14.29 \%$. It indicated that $85.71 \%$ of VHS students were very true that their career aspirations were not related to the study program they were taking at vocational high school. Nevertheless, 50\% of VHS students were true that their career aspirations were related to their study program they were taking at vocational high school. It meant that most VHS students did not have mature career aspirations to the study program they were taking at vocational high school.

The findings confirmed the previous studies, Sumantri (2013) stated that many VHS students have low maturity of a career that is still changing, unrealistic, not independent, and hesitant in making career decisions. One of the factors that allegedly influenced the career maturity of vocational students is a career aspiration factor; it is the most fundamental factor in influencing career maturity. It causes them to be in trouble situations to decide their future career and their preparation to achieve their career aspiration. Fakhri and Yufridawati (2009) on their research held in 12 vocational high schools (VHSs) majoring automotive mechanical engineering at four selected districts (Padang, Kendari, Agam, and Kolaka), the finding found that only a small proportion of informants claimed to be employed by the skills that they learned at school. Meanwhile, for those who are in university, many graduates do not choose the same skill they have gotten in school. Students' lack of experience or even unconsciousness about the importance of having a career aspiration is one of the factors of the wrong choice of career. Their real career is different from a skill that has been learned in school. Salami (cited in Reddy \& Rajaram, 2015) many students made wrong choices in their careers because of ignorance, inexperience, peer pressure, advice from friends, parents, and teachers, or tags attached to certain job types without adequate knowledge.

\section{The Effect of VHS Students' Perception (EGP and ESP) on their Career Aspirations}

This sub-section focused the effect of students' perception (EGP and ESP) on their career aspirations. A multiple linear regression analysis used to test the effect of students' perception of their English program (EGP and ESP) on their career aspirations variables.

Table 12. Regression Analysis Summary of Students' Perception of their English program (EGP and ESP) on Students' Career Aspiration

\begin{tabular}{lrrrrr}
\hline Model & $\boldsymbol{R}$ & $\boldsymbol{R}$ Square & Adjusted $\mathbf{R}$ Square & Std. Error of the Estimate & \multicolumn{1}{c}{ Sig. } \\
\hline 1 & $.467^{\mathrm{a}}$ & .218 & .215 & .29176 & $.000^{\mathrm{b}}$ \\
\hline
\end{tabular}

a. Predictors: (Constant), English for Specific Purposes, English for

General Purposes

Based on the table, it showed that Adjusted $R$ Square $=0.215$. It meant that the independent variable "perception (EGP and ESP)" has a contribution of $21.5 \%$ to the dependent variable "career aspiration". Furthermore, the significant $(p)=0.000$ $<0.05$ indicating it was significant. It meant that independent variable "perception (EGP and ESP)" significantly predict dependent variable "career aspiration". 
Table 13. Coefficient Regression Summary Predicting Students'Career Aspiration

\begin{tabular}{|c|c|c|c|c|c|}
\hline \multirow[t]{2}{*}{ Model } & \multicolumn{2}{|c|}{$\begin{array}{l}\text { Unstandardized } \\
\text { Coefficients }\end{array}$} & $\begin{array}{c}\text { Standardized } \\
\text { Coefficients }\end{array}$ & \multirow[t]{2}{*}{$t$} & \multirow[t]{2}{*}{ Sig. } \\
\hline & $B$ & Std. Error & Beta & & \\
\hline 1 (Constant) & 2.050 & .097 & & 21.136 & .000 \\
\hline EGP & .185 & .034 & .238 & 5.484 & .000 \\
\hline ESP & .170 & .024 & .307 & 7.066 & .000 \\
\hline
\end{tabular}

a. Dependent Variable: Career Aspiration

This table explained the regression equation model obtained with constant coefficients and variable coefficients in the unstandardized Coefficients $B$. It meant that if there was 1 score on the independent variable "students' perception of EGP" increasing, it would increase the score of dependent variable "students' career aspiration" as much as 0.185 and vice versa. Meanwhile for ESP, if there was 1 score on the independent variable "students' perception of ESP" increasing, it would increase the score of dependent variable "students' career aspiration" as much as 0.170 and vice versa.

T-test was used to test the significance of constant value and dependent variable "career aspiration". It showed that the independent variable "Perception of EGP and ESP" significantly affect dependent variable "career aspiration" ( $p=$ $0.000<0.01)$. The results had statistically shown that there was a significant the effect of students' perception of their English program (EGP and ESP) on their career aspirations. Therefore, the first hypothesis was accepted.

This finding supported the previous study Hua and Beverton (2013) said that VHS students aim to learn English to benefit their future career development, by gaining the language ability to interact with foreigners. This seems to show that they learn English for practical reasons rather than simply the 'academicallyoriented' reason for passing exams. It meant that what the students chose about the type of English program (EGP and ESP) would significantly affect their career aspirations. Therefore, Hua and Beverton (2013) also said that "learning English for career development" is regarded as the students' top purpose, goal, and need for learning English. They were able to decide what type of English program they deemed to be appropriate after deciding what their career aspiration. Warden and Lin (cited in Hua \& Beverton, 2013) their study have shown that students have strong instrumental motivation in their English studies, associated with career improvement. They were able to predict what was needed in achieving their career aspiration.

\section{The Differences between VHS Students' Perception of their English Program (EGP and ESP) based on Demographic Variables}

This sub-section focused on the differences between VHS students' perception of their English program (EGP and ESP) based on demographic variables. MANOVA used to test whether students' perception of English program (EGP and ESP) was differed by (1) gender (i.e. male and female) and (2) study program (i.e. Hospitality, Culinary Arts, Computer Engineering, and Automobile). The following tables were the results of the MANOVA test. 
Table 14. Box's Test of Equality of Covariance Matrices

\begin{tabular}{lr}
\hline Box's $M$ & 19.320 \\
\hline$F$ & 1.597 \\
\hline$d f 1$ & 18 \\
\hline$d f 2$ & 5151.074 \\
\hline Sig. & .175 \\
\hline
\end{tabular}

Box's $M$ was used to examine the homogeneity of variance-covariance of the two dependent variables together. From the table it was seen that box's $M$ coefficient $=19.320, F=1.597$, and $P=0.175>0.05$. Therefore, further analysis can be continued.

Table 15. Multivariate Tests

\begin{tabular}{|c|c|c|c|c|c|c|}
\hline Effect & & Value & $F$ & Hypothesis df & Error df & Sig. \\
\hline \multirow[t]{4}{*}{ Intercept } & Pillai's Trace & .704 & $615.069^{b}$ & 2.000 & 517.000 & .000 \\
\hline & Wilks' Lambda & .296 & $615.069^{b}$ & 2.000 & 517.000 & .000 \\
\hline & Hotelling's Trace & 2.379 & $615.069^{b}$ & 2.000 & 517.000 & .000 \\
\hline & Roy's Largest Root & 2.379 & $615.069^{b}$ & 2.000 & 517.000 & .000 \\
\hline \multirow[t]{4}{*}{ Gender } & Pillai's Trace & .022 & 2.822 & 4.000 & 1036.000 & .024 \\
\hline & Wilks' Lambda & .978 & $2.832^{\mathrm{b}}$ & 4.000 & 1034.000 & .024 \\
\hline & Hotelling's Trace & .022 & 2.841 & 4.000 & 1032.000 & .023 \\
\hline & Roy's Largest Root & .022 & $5.651^{c}$ & 2.000 & 518.000 & .004 \\
\hline \multirow{4}{*}{$\begin{array}{l}\text { Study } \\
\text { Program }\end{array}$} & Pillai's Trace & .130 & 12.018 & 6.000 & 1036.000 & .000 \\
\hline & Wilks' Lambda & .870 & $12.385^{\mathrm{b}}$ & 6.000 & 1034.000 & .000 \\
\hline & Hotelling's Trace & .148 & 12.750 & 6.000 & 1032.000 & .000 \\
\hline & Roy's Largest Root & .144 & $24.835^{c}$ & 3.000 & 518.000 & ,000 \\
\hline \multirow{4}{*}{$\begin{array}{l}\text { Gender * } \\
\text { Study } \\
\text { Program }\end{array}$} & Pillai's Trace & .006 & .824 & 4.000 & 1036.000 & 510 \\
\hline & Wilks' Lambda & .994 & $.823^{\mathrm{b}}$ & 4.000 & 1034.000 & .511 \\
\hline & Hotelling's Trace & .006 & .822 & 4.000 & 1032.000 & .511 \\
\hline & Roy's Largest Root & .006 & $1.451^{c}$ & 2.000 & 518.000 & .235 \\
\hline
\end{tabular}

a. Design: Intercept + Gender + StudyProgram + Gender * StudyProgram

b. Exact statistic

c. The statistic is an upper bound on $\mathrm{F}$ that yields a lower bound on the significance level.

The variable "gender" showed the result that the gender of students "male and female" were significantly different from the students' perception of the two types of English program "EGP and ESP" ( $p=0.024 ; 0.024 ; 0.023$; and $0.004<0.05)$. Furthermore, the variable "study program" also showed that the four study programs were significantly different from students' perceptions of the two types of English program "EGP and ESP" ( $p=0.000<0.05)$. The results had statistically shown that there was a significant difference in students' perception of their English program due to a difference in gender and study program. Meaning that male and female students and the students from four study programs distinguished the types of English (EGP and ESP) they wanted to learn. Therefore, the second and third hypotheses were accepted. 
The finding of students' gender (i.e. male and female) was in line with Jones et al. (cited in Haney, 2002) stated that understanding their perceptions or mental models of vocational education programs and the factors supporting the crystallization of those perceptions as determined by gender, race, academic performance, career awareness, and socio-economic factors. The difference between male and female students in the second language, especially in English learning should attract the attention of students and teachers (Qian, 2015). It is supported by Moiinvaziri (2014) stated that females like the English language more than males.

Furthermore, the finding of students' study program (i.e. hospitality, culinary arts, computer engineering, and automotive) was supported by Hua \& Beverton (2013) on their research for Taiwanese students in vocational high school. In terms of the question, "English learned in school that is general English is relevant to VHS students' future anticipated career, students from tourism and restaurant management agree more than the other two groups (data processing and automobile) that the English learned in school that is general English is relevant to their future anticipated career.

In the Indonesian context, this finding was also in line with the need analysis conducted by study Mahbub and Fauzi (2018) on computer engineering students. It was found that the majority of students $90.62 \%$ stated that they needed a material that contained terms or expressions to communicate with others and $78.12 \%$ of students wanted to learn topics related to daily life. It was supported by Al-Hafizh and Ratmanida (2008) on their research held in UNP Padang culinary arts study program. The finding found that hospitality staff in the city of Padang need all four English language skills (reading, writing, speaking, and listening skills) along with topics related to the hospitality industry.

\section{CONCLUSION}

First, the findings of this study provide evidence that most VHS students' English perceived need was ESP. Nevertheless, it was also undeniable that they also still needed EGP for their English before they take ESP. The two types of English program (EGP and ESP) are needed and complement each other. EGP is their provision in general communication. Meanwhile, ESP is their provision in specific communication related to their study program. Furthermore, the result also becomes enlightenment on two different views on the types of English that is suitable for VHS students between English teachers and government. There is no longer a difference in views between the English teacher and the government. Therefore, the researchers recommend equipping vocational students with both types of English. EGP for their general English communication, ESP as supplementary material for their specific English focuses on their study programs to strengthen their ability to deal with the AEC era.

Second, most VHS students did not have mature career aspirations for the study program they were taking at school. Therefore, it is important to the VHS' teachers provide an understanding of the importance of having career aspirations, strengthening students' career aspirations for VHS students who do not have mature career aspirations, and providing career counseling and advising at schools 
to identify students' career aspirations and the way how they can approach their careers.

Third, VHS students' perception (EGP and ESP) significantly affects their career aspirations so that students' perception (EGP and ESP) can be used to predict their career aspirations. Fourth, VHS students' gender and study programs significantly distinguish the types of English (EGP and ESP) they wanted to learn so that gender and differences in study programs can be used to determine the type of English program (EGP and ESP) they want.

\section{REFERENCES}

Act of the Republic Indonesia number 20 year 2003 on National Education System. Ahen, J., A. (2009). Student's Perception towards English for Self-Expression. Thesis Bachelor, unpublished. University of Malaysia Serawak.

Al-Hafizh, M., \& Ratmanida. (2008). Analisis Kebutuhan Bahasa Inggris Jurusan Tata Boga - PKK UNP Padang. Lingua Didaktika, 1 (2), 1-14.

Arslan, M. U., \& Akbarov, A. (2012). EFL Learners Perceeption and Attitudes Towards English for Specific Purposes. Acta Didactica Napocensia, 5(4), 25-30.

Badan Pusat Statistik (BPS). (2013). Proyeksi Penduduk Indonesia 2010-2035. Jakarta: Badan Pusat Statistik.

Evans, R. N., \& Edwin, L. H. (1978). Foundation of Vocational Education. Columbus, $\mathrm{OH}$ : Charles E. Merril Publishing Company.

Fakhri, E., \& Yufridawati. (2009). Relevansi Kompetensi dan Tingkat Daya Saing Lulusan SMK dalam Dunia Kerja (Study Kasus pada SMK Teknik Otomotif di Empat Kabupaten Kota). Article, unpublished. STAI Al-Ihya Kuningan, Jawa barat.

Feng, Z. (2013). A Study on the Perceptions of Secondary School Students Regarding the Form-Focused and Communication-Focused English Instruction. English Linguistics Research, 2(2), 43-52. doi.org/10.5430/elr.v2n2p43.

Gregor, M. A., \& O’ Brien, K. (2016). Understanding career Aspirations among Young Women: Improving Instrumentation. Dissertation, unpublished, University of Maryland, College Park.

Hajjar, S. T. (2014). A Statistical Study to Develop a Reliable Scale to Evaluate Instructors within Higher Institutions. Wseas Transactions on Mathematics, 13, 885-894.

Haney, R. M. (2002). Secondary Student Perceptions of Vocational Education. University of Florida Digital commons. Dissertation, unpublish. University of Florida, USA.

Hua, T.-L., \& Beverton, S. (2013). General or Vocational English Courses for Taiwanese Students in Vocational High Schools? Students' Perceptions of their English Courses and their Relevance to their Future Career. Educ Res Policy Prac, 12, 101-120. doi.org/10.1007/s10671-012-9137-x.

Hutchinson, T., \& Waters, A. (1987). English for Specific Purposes: A Learning-Centred Approach. Cambridge: University Press.

Kusni, Syamwil, \& Refnaldi. (2014). Diagnosing the Needs for English at Vocational Schools: Redesign the Curriculum 2013?. Proceeding of the Third International Seminar on Languages and Arts, 300-307. 
Lerdpornkulrat, T., Koul, R., \& Sujivorakul, C. (1999). Career Aspiration and the Influence of Parenting Styles: A Review of the Literature. Educational Technology, 71-76.

Linderman., A., J. (2010). Seventh Grade Student Career Aspirations and Academic Achievement. Thesis Master, unpublished. The College at Brockport.

Mahbub, M. A., \& Fauzi, F. (2018). Identifikasi kebutuhan bahasa inggris siswa SMK TKJ melalui Pendekatan need analysis. Prosiding Seminar Nasional Hasil Penelitian dan Pengabdian kepada Masyarakat III, Tuban, 3, 116-121.

Moiinvaziri, M. (2014). Students' Voice: A Needs Analysis of University General English Course in Iran. Journal of Language Studies, 14(February), 57-75.

Nurgiyantoro, B., Gunawan, and Marzuki. (2015). Statistik Terapan untuk Penelitian Ilmu Sosial ( $5^{\text {th }}$ ed.). Yogyakarta: Gadjah Mada University Press.

Pfingst, C. (2015). Girls' Career Aspirations: The Impact of Parents' Economic and Educational Status on Educational and Career Pathways. Thesis Master, unpublished. Queensland University of Technology.

Qian, W. (2015). A Study of the Influence of Gender Differences on English Learning of Senior High School Students. Higher Education of Social Science, 8(6), 6669. doi.org/10.3968/7173.

Rahmat, A., \& Al As'ary, M. (2017). The Application of EGP Materials to ATC Students of Casea Makassar. Leksema, 2 (1), 65-75.

Reddy, G. C., \& Rajaram, N. J. (2015). Career Aspirations and Background of Students Opting for Fashion Education Courses in India. Procedia - Social and Behavioral Sciences, 176, 952-960. doi.org/10.1016/j.sbspro.2015.01.564.

Sumantri, D. (2013). Pengaruh Faktor Aspirasi Pekerjaan dan Aspirasi Jurusan terhadap Kematangan Karir Siswa SMK Jurusan Otomotif di DIY 2012/2013. Thesis Bachelor, unpublished. Universitas Negeri Yogyakarta,Yogyakarta.

Tabatabaei, O., \& Mokhtari, A. (2014). ESP Learners' Perception of ESP Program Problems at Iranian Universities (A Case Study of Islamic Azad University Najafabad Branch). Theory and Practice in Language Studies: Academy Publisher, 4 (6), 1144-1154. doi:10.4304/tpls.4.6.1144-1154.

Trimble, L. (1985). English for Science and Technology: A Discoursal Approach. Cambridge: Cambridge University Press. 